\title{
Implementasi Model Pembelajaran Reciprocal Teaching untuk Meningkatkan Motivasi dan Hasil Belajar Pemrograman Dasar Kelas X TKJ SMK Negeri 1 Painan
}

\author{
Zuryana $^{1^{*}}$ \\ ${ }^{1}$ Teknik Komputer Jaringan, SMK Negeri 1 Painan \\ *e-mail: zuryana@ft.unp.ac.id \\ (Diajukan: 29 Januari 2021, direvisi: 16 Februari 2021, disetujui: 17 Februari 2021)
}

\begin{abstract}
Abstrak
Penelitian ini dilatar belakangi dengan adanya fenomena yang peneliti temukan dilapangan yaitu rendahnya motivasi belajar siswa dikarenakan siswa hanya mendengarkan dan mencatat, sehingga dalam hal ini mempengaruhi hasil dan motivasi belajar siswa. Penelitian ini bertujuan untuk mengetahui implementasi model pembelajaran Reciprocal teaching untuk meningkatkan motivasi belajar siswa dan KKM Pemrrograman Dasar Kelas X TKJ SMK Negeri 1 Painan. Subjek penelitian ini adalah siswa kelas X TKJ SMK Negeri 1 Painan tahun ajaran 2020/ 2021, dengan menggunakan model penelitian tindakan kelas (PTK) bersifat kolaboratif, dengan teknik analisis data kualitatif dan kuantitatif. Penelitian ini menggunakan II siklus dan tiap siklus dua kali pertemuan. Kegiatan tiap siklus terdiri dari: perencanaan, pelaksanaan, pengamatan dan refleksi.. Berdasarkan hasil lembar observasi selama penelitian, menunjukan bahwa rata-rata persentase motivasi belajar pada siklus I adalah 58\% dalam kategori baik, rata-rata persentase motivasi belajar pada siklus II $77 \%$ dalam kategori sangat baik. Peningkatan hasil belajar siswa kelas X TKJ SMK Negeri 1 Painan dilihat dari ketuntasan klasikal pada tes siklus I dan tes siklus II berturut-turut $41 \%$ dan $81 \%$.Kesimpulan dari penelitian ini adalah implementasi model pembelajaran reciprocal teaching dapat meningkatkan motivasi dan hasil belajar siswa.
\end{abstract}

Kata Kunci: motivasi belajar, hasil belajar, model pembelajaran reciprocal teaching .

\begin{abstract}
While such this study the phenomenon that researchers find that is the lack of motivation he student learning because they just listen and record, so in this affects the student learning and motivation. The study aimed to identify the reciprocal kind of classroom teaching students and to increase the motivation to study KKM Programmer class X TKJ SMKN 1 Painan. The subject of this research is students X TKJ SMKN 1 Painan academic year 2020 / 2021, using a model research (PTK) (class action is collaborative, of qualitative and quantitative data analysis. This study using ii cycle and each cycle two meetings. Activities in each consisting of: , planning cycle the implementation of, observation and reflection. Based on the sheets of observation, during the study showed that the percentage of rata-rata motivation to learn on the cycle $\mathrm{i}$ is $58 \%$, good category in the percentage of rata-rata motivation to learn on the cycle ii $77 \%$ category in a very good.An increase in student learning outcomes class X TKJ SMKN 1 Painan seen from exhaustiveness klasikal on the test cycle test cycle I and II $41 \%$ and $81 \%$. the conclusion from this research is kind of classroom teaching reciprocal implementation can improve motivation and student learning outcomes.
\end{abstract}

Keywords: the motivation to study, learning outcomes, reciprocal ran kind of classroom. 


\section{PENDAHULUAN}

Berdasarkan hasil observasi di SMK Negeri 1 Painan khususnya kelas X TKJ dari sampel jumlah 37 siswa semester I tahun pelajaran 2020/ 2021 pada mata pelajaran pemrograman dasar, didapatkan presentase jumlah siswa yang mencapai KKM sebesar 24\% atau sekitar 9 orang, 76\% jumlah siswa dibawah KKM atau sekitar 28 orang. Perbedaan prestasi belajar siswa menurut keterangan dari guru mata pelajaran berdasarkan hasil wawancara tahun 2020 hasil ini disebabkan karena kemampuan anak yang bervariatif dan daya kemampuan siswa menangkap materi yang rendah. Hal ini disebabkan karena faktor kesadaran akan arti penting belajar masih rendah dan sekolah belum menjadi kebutuhan bagi mereka.

Berdasarkan penelitian Harahap [1] yang berjudul" Implementasi Pendekatan Reciprocal Teaching dengan Strategi Pembelajaran Card Sort untuk Meningkatkan Aktivitas dan Hasil Belajar Akuntansi Siswa Kelas XII BM SMK Muhammadiyah 8 Medan Tahun Pembelajaran 2017/ 2020 ". Berdasarkan hasil penelitiannya menunjukan bahwa hasil belajar siswa meningkat. Hal ini terbukti dari hasil yang diperoleh pada siklus I nilai rata-rata 65 dengan persentase ketuntasan belajar siswa sebesar $56,25 \%$ dan pada siklus II diperoleh nilai ratarata 76,71 dengan persentase ketuntasan belajar siswa sebesar 90,62\%. Dimana peningkatan nilai kemampuan siswa antar siklus I ke siklus II adalah 11,71 untuk hasil belajar akuntansi dengan peningkatan persentase 34,37\%. Sedangkan berdasarkan penelitian Ade Gita Valentino [2] yang berjudul "Penerapan Pendekatan Strategi Pengajaran Timbal Balik (Reciprocal Teaching) untuk Meningkatkan Kemampuan Berkomunikasi, Prestasi dan Motivasi Belajar pada Mata Pelajaran Pengetahuan Dasar Teknik Mesin Siswa Kelas X di SMKN 6 Malang” dari hasil penelitan menunjukan hasil dari keadaan awal 55\% siswa sering mendapatkan remidi setelah di terapkan model pembelajaran Reciprocal teaching meningkat pada siklus I adalah $73,5 \%$ dan pada siklus II sebesar $89 \%$, peningkatan hasil belajar sekitar $15,5 \%$. Sedangkan motivasi belajar siswa meningkat dari keadaan awal tidak semua siswa antusias dalam mengikuti pembelajaran itu terbukti dengan banyaknya siswa yang kurang memperhatikan pembelajaran dan kurangnya antusias bertanya pada guru mengalami peningkatan sebesar 7,15\%.

Terkait dengan hasil penelitian yang relevan dan permasalahan-permasalahan yang telah ditemukan di SMK Negeri 1 Painan maka untuk mengatasi masalah-masalah terhadap motivasi dan nilai KKM, peneliti menawarkan strategi model pembelajaran yaitu model pembelajaran Reciprocal Teaching. Allen [3] menerangkan bahwa model pembelajaran Reciprocal Teaching merupakan suatu prosedur pembelajaran yang di desain untuk meningkatkan pemahaman dan nalar siswa terhadap suatu materi.

Reciprocal Teaching atau pembelajaran timbal balik memusatkan perhatian pada proses berfikir anak, selain itu pembelajaran ini mengutamakan peran siswa untuk berinisiatif adan berperan aktif. Guru memberikan kesempatan kepada siswa menjadi aktif dengan melakukan pergantian peran. Siswa berperan sebagai guru di dalam kelas, sedangkan guru hanya sebagai fasilitator atau moderator. Model pembelajaran reciprocal teaching menggunakan empat strategi yaitu: merangkum, membuat pertanyaan, mengklarifikasi (menjelaskan), dan memprediksi. Masingmasing strategi tersebut dapat membantu siswa membangun pemahaman terhadap apa yang sedang dipelajari. Berdasarkan pada permasalahan-permasalahan yang telah dijelaskan, maka penulis melakukan penelitian dengan menerapkan model pembelajaran yang berbeda.

\section{A. Motivasi Belajar}

Motif dapat dikatakan sebagai daya penggerak dari dalam dan di dalam subjek untuk melakukan aktivitas-aktivitas tertentu demi mencapai suatu tujuan. Sebenarnya motivasi merupakan istilah yang lebih umum untuk menunjuk pada seluruh proses gerakan,termasuk situasi yang mendorong,dorongan yang timbul dalam diri individu, 
tingkah laku yang ditimbulkannya,dan tujuan atau akhir dari perbuatan [4]. Menurut [4] Motivasi merupakan perubahan energi dalam diri seseorang yang ditandai dengan munculnya "feeling" dan didahului dengan tanggapan terhadap adanya tujuan. Pada hakikatnya motivasi di pengaruhi oleh beberapa faktor seperti siswa yang memiliki intelegensia cukup tinggi, boleh jadi gagal karena kekurangan motivasi. Hasil belajar akan optimal kalau ada motivasi yang tepat. Maka dari itu, kegagalan belajar siswa jangan begitu saja mempersalahkan pihak siswa, sebab mungkin saja guru tidak berhasil dalam memberi motivasi yang mampu membangkitkan semangat dan kegiatan siswa untuk berbuat/belajar. Motivasi belajar, pada umumnya memiliki beberapa indikator atau unsur yang mempunyai peranan dalam keberhasilan seseorang. Indikator motivasi belajar menurut [5] dapat diklasifikasikan sebagai berikut:

1) adanya hasrat dan keinginan berhasil

2) adanya dorongan dan kebutuhan dalam belajar

3) adanya harapan dan cita-cita masa depan

4) adanya penghargaan dalam belajar

5) adanya kegiatan yang menarik dalam belajar

6) adanya lingkungan belajar yang kondusif sehingga memungkinkan seseorang siswa dapat belajar dengan baik.

Menurut De Dece dan Grawford [6] "Ada empat fungsi guru sebagai pengajar yang berhubungan dengan cara pemeliharaan dan peningkatan motivasi belajar anak didik, yaitu guru harus dapat menggairahkan anak didik, memberikan harapan yang realistis, memberikan insentif, dan mengarahkan perilaku anak didik kearah yang menunnjang tercapainya tujuan pengajaran.” Memotivasi belajar penting artinya dalam proses belajar siswa,karena fungsinya yang mendorong, menggerakan, dan mengarahkan kegiatan belajar [7].

B. Hasil Belajar

Hasil belajar siswa memang menjadi tolak ukur dalam proses pembelajaran. Hal tersebut dapat di ketahui melalui berbagai macam penilaian, selain itu hasil belajar ditandai adanya perubahan aktivitas siswa. Sejalan dengan hal tersebut, menurut Hamalik [8] hasil belajar tampak sebagai terjadinya perubahan tingkah laku pada diri siswa, yang dapat diamati dan diukur dalam bentuk perubahan pengetahuan, sikap, dan keterampilan. Perubahan tersebut dapat diartikan terjdainya peningkatan dan pengembangan yang lebih baik dibandingkan dengan sebelumnya, misalnya dari yang tidak tahu, sikap kurang sopan menjadi sopan, dan lainnya. Menurut Hamalik [8] menyatakan bahwa hasil belajar merupakan perubahan peilaku yang diperoleh peserta didik setelah mengalami kegiatan belajar. Sedangkan menurut Carl [9] menyatakan hasil belajar siswa di sekolah $70 \%$ dipengaruhi oleh kemampuan siswa dan $30 \%$ dipengaruhi lingkungan. Adanya pengaruh dalam siswa merupakan hal yang wajar, sebab kemampuan siswa berbeda-beda dalam segi kognitif, afektif, dan psikomotorik. Pernyataan tersebut dikemukan juga oleh Benyamin S. Bloom dalam Rifa'i [9] hasil belajar yang hendak dicapai harus meliputi ranah belajar, yaitu: ranah kognitif, ranah afektif, dan ranah psikomotorik.

Hasil belajar sesuai dengan kurikulum 2013 di tetapkan dalam Kriteria Ketuntasan Minimum (KKM) merupakan Kriteria Ketuntasan Belajar (KKB) yang ditetapkan oleh satuan pendidikan. Penentuan KKM ditetapkan oleh satuan pendidikan dan KKM yang telah ditentukan oleh pemerintah [10]. Menurut Wina Sanjaya [11] dalam kurikulum, kompetensi sebagai tujuan pembelajaran itu dideskripsikan secara eksplisit, sehingga dijadikan standar dalam pencapaian tujuan kurikulum. Baik guru maupun siswa perlu memahami kompetensi yang harus dicapai dalam proses pendidikan dan pembelajaran.

Pemahaman ini diperlukan untuk memudahkan dalam merancang strategi dan indikator keberhasilan dan ketuntasan belajar dikatakan berhasil apabila terjadi 
perubahan perilaku yang positif pada diri peserta didik atau setidaknya kurang lebih 75 $\%$ menurut Mulyasa dalam Nisa [12]. Berdasarkan beberapa pendapat menurut Anni, dkk [9], maka hasil belajar merupakan proses perubahan tingkah laku peserta didik setelah mengalami kegiatan belajar yang ditandai dengan perubahan aktivitas yang meliputi beberapa penilaian pengetahuan, keterampilan, dan sikap.

C. Model Pembelajaran Reciprocal Teaching

Menurut Manohar [12] model reciprocal teaching tidak hanya membantu memahami bacaan tetapi juga memberikan kesempatan bagi siswa untuk memantau sendiri proses belajar dan berpikir. Reciprocal Teaching merupakan strategi belajar melalui kegiatan mengajarkan teman, di mana siswa berperan sebagai "guru" menggantikan peran guru untuk mengajarkan temantemannya. Sementara itu guru lebih berperan sebagai model yang menjadi contoh, fasilitator yang memberi kemudahan, pembimbing yang melakukan scaffolding (bimbingan yang diberikan oleh orang yang lebih tahu kepada orang yang kurang tahu). Model Reciprocal Teaching (Pengajaran Timbal Balik) [13] merupakan model pengajaran yang diciptakan oleh Ann Brown dan Anne Marie Pallinscar. Ada beberapa definisi mengenai pengajaran terbalik dan semua definisi tersebut pada dasarnya memiliki pengertian yang sama. Reciprocal Teaching adalah pendekatan konstruktivis didasarkan pada prinsip pengajuan pertanyaan, mengajar ketrampilan metakognitif melalui pengajaran dan pemodelan guru untuk memperbaiki kinerja siswa yang memiliki pemahaman rendah [13]. Menurut Nur Efendi [13] Pengajaran timbal balik (Reciprocal Teaching) adalah pembelajaan yang berpusat pada siswa dimana siswa dan guru beralih peran dalam pelajaran dan termasuk dalam pembelajaran kooperatif dimana dialog yang mengungkapkan peserta didik proses berpikir tentang pengalaman belajar.

\section{METODE}

Jenis penelitian yang digunakan dalam penelitian ini yaitu penelitian tindakan kelas (Classroom Action Research). Adapun tahapan dalam penelitian tindakan yaitu perencanaan (Planning), Tindakan atau aksi (Acting) Pengamatan (Observing), Refleksi (Reflecting). Penelitian ini dilaksanakan di SMK Negeri 1 Painan yang beralamat di Jalan Jl. DR Muhammad Hatta Painan Kecamatan IV Jurai Kabupaten Pesisir Selatan Provinsi Sumatera Barat. Penelitian dimulai pada semester ganjil tahun pelajaran 2020/ 2021 pada bulan Juli 2020 sampai dengan September 2020. Subjek dan Objek penelitian yaitu siswa kelas X TKJ berjumlah 37 siswa yang mengikuti pembelajaran Pemograman Dasar di SMK Negeri 1 Painan.

Teknik pengumpulan data menggunakan instrumen tes kognitif, tes ketrampilan, dan lembar observasi motivasi belajar siswa. Peningkatan hasil belajar ditandai dengan tercapainya Hasil Belajar $\geq 75$ secara individual dan kurang lebih mencapai 75\% secara klasikal baik penilaian praktik dan juga observasi motivasi belajar siswa. Data hasil penelitian yang sudah terkumpul selanjutnya dilakukan analisa. Data hasil observasi dianalisa secara deskriptif kualitatif, sedangkan data hasil tes evaluasi dianalisa secara kuantitatif.

\section{HASIL DAN PEMBAHASAN}

Berdasarkan hasil observasi dalam kegiatan belajar siswa cenderung kurang memperhatikan penjelasan guru dan keadaan kelas yang ribut serta siswa jarang mengerjakan. Sebelum kegiatan penelitian dilakukan, untuk mengukur motivasi belajar 
siswa peneliti menggunakan angket untuk mengetahui tingkat motivasi belajar siswa, data dapat disajikan dalam table 1 .

Tabel 1. Persentase Pra Penelitian Hasil Angket

\begin{tabular}{ccccc}
\hline No & Interval & Kriteria & Jumlah & Persentase (\%) \\
\hline 1 & $25 \%-40 \%$ & Sangat Rendah & 2 & 5,4 \\
2 & $41 \%-55 \%$ & Rendah & 17 & 45,94 \\
3 & $56 \%-70 \%$ & Sedang & 13 & 35,13 \\
4 & $71 \%-85 \%$ & Tinggi & 4 & 10,81 \\
5 & $86 \%-100 \%$ & Sangat Tinggi & 1 & 2,70 \\
\hline \multicolumn{2}{l}{ Rata-rata } & & $52,09 \%$ \\
& Kriteria & & Rendah \\
\hline
\end{tabular}

Berdasarkan data pra penelitian menunjukan perlu adanya tindakan untuk meningkatkan motivasi belajar siswa. Tindakan yang dilakukan adalah meningkatakan motivasi belajar melalui model pembelajaran Reciprocal teaching. Pada tabel 2 disajikan perbandingan motivasi belajar siklus I dan siklus II berdasarkan indikator motivasi belajar.

Tabel 2. hasil pengamatan motivasi belajar siklus I dan siklus II

\begin{tabular}{|c|c|c|c|c|c|}
\hline \multirow{2}{*}{ Indikator } & \multicolumn{2}{|c|}{ Siklus I } & \multicolumn{2}{|c|}{ Siklus II } & \multirow{2}{*}{$\begin{array}{c}\text { Peningkatan } \\
(\%)\end{array}$} \\
\hline & Frekuensi & $\%$ & Frekuensi & $\%$ & \\
\hline Tekun menghadapi tugas & 25 & $67 \%$ & 30 & $80 \%$ & $13 \%$ \\
\hline Ulet menghadapi kesulitan & 20 & $55 \%$ & 25 & $75 \%$ & $20 \%$ \\
\hline Minat terhadap masalah & 24 & $64 \%$ & 28 & $78 \%$ & $14 \%$ \\
\hline $\begin{array}{c}\text { Senang bekerja mandiri dalam } \\
\text { kelompok }\end{array}$ & 20 & $54 \%$ & 27 & $76 \%$ & $22 \%$ \\
\hline $\begin{array}{l}\text { Senang mencari dan } \\
\text { memecahkan masalah }\end{array}$ & 19 & $50 \%$ & 28 & $77 \%$ & $27 \%$ \\
\hline Rata-rata keseluruhan & - & $58 \%$ & - & $77 \%$ & $19 \%$ \\
\hline
\end{tabular}

Berdasarkan tabel 2, dapat digolongkan dalam tabel kriteria motivasi belajar siswa. Berikut tabel 3 kriteria motivasi belajar siswa.

Tabel 3 kriteria motivasi belajar siswa siklus I dan siklus II

\begin{tabular}{ccccccc}
\hline No & Rentang & Kriteria & \multicolumn{2}{c}{ Frekuensi } & \multicolumn{2}{c}{ Persentase } \\
& & & Siklus I & Siklus II & Siklus I & Siklus II \\
\hline 1 & $75 \%<$ rata-rata $\leq 100 \%$ & Sangat Baik & 3 & 21 & $8 \%$ & $57 \%$ \\
2 & $50 \%<$ rata-rata $\leq 75 \%$ & Baik & 24 & 9 & $65 \%$ & $24 \%$ \\
3 & $25 \%<$ rata-rata $\leq 50 \%$ & Cukup Baik & 8 & 7 & $22 \%$ & $19 \%$ \\
4 & $0 \% \leq$ rata-rata $\leq 25 \%$ & Kurang Baik & 2 & 0 & $5 \%$ & $0 \%$ \\
\hline Jumlah & & 37 & 37 & $100 \%$ & $100 \%$ \\
\hline
\end{tabular}

Data pada gambar 1 menunjukan perbandingan yang signifikan antara siklus I dan siklus II. Hasil pada siklus II mengalami peningkatan dari keadaan pada siklus I dengan rata-rata persentase peningkatan sebesar $22 \%$. 


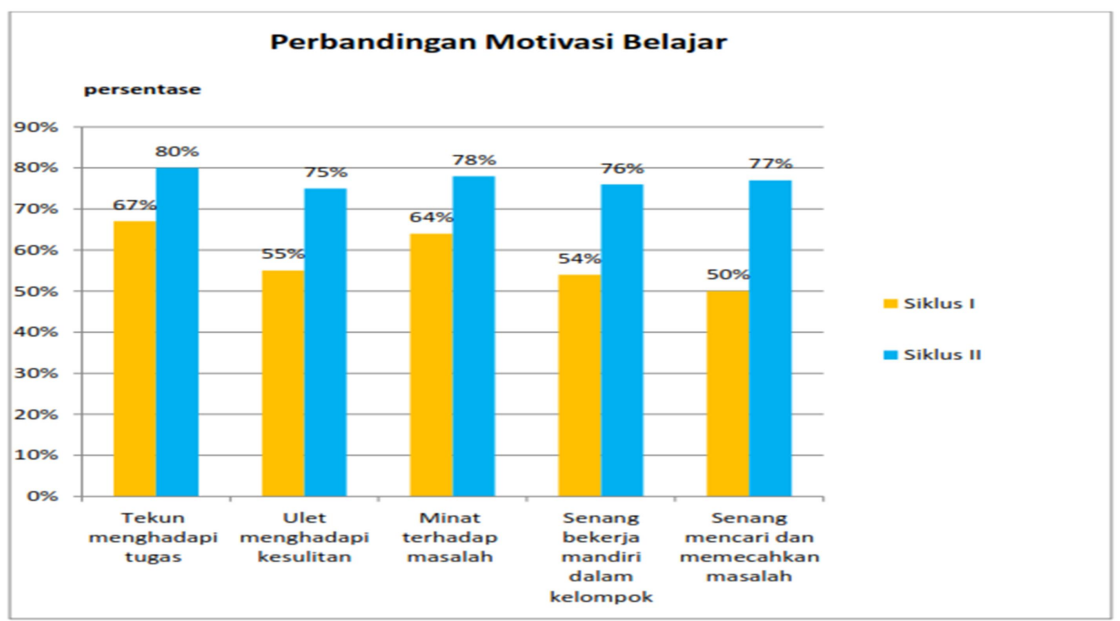

Gambar 1. Persentase perbandingan motivasi belajar siklus I dan siklus II

Tes evaluasi digunakan untuk mengukur kemampuan siswa dalam memahami materi pembelajaran yang telah diajarkan dan untuk hasil tes evaluasi siswa siklus I dan siklus II dapat dilihat pada tabel 4.

Tabel 4. hasil nilai tes evaluasi siklus I dan siklus II

\begin{tabular}{clcc}
\hline No & \multicolumn{1}{c}{ Hasil Tes } & Siklus I & Siklus II \\
\hline 1. & Nilai tertinggi & 84 & 92 \\
2. & Nilai terendah & 32 & 48 \\
3. & Rata-rata & 65,6 & 76,6 \\
4. & Jumlah siswa tuntas & 15 & 30 \\
5. & Jumlah siswa tidak tuntas & 22 & 7 \\
6. & Persentase ketuntasan KBM & $41 \%$ & $81 \%$ \\
\hline
\end{tabular}

Berdasarkan data pada tabel 4 diketahui bahwa adanya suatu peningkatan hasil evaluasi belajar siswa dari pra penelitian, siklus I, dan siklus II. Adanya peningkaan pada evaluasi belajar siswa dapat dilihat dari nilai rata-rata siswa dan persentase ketuntasan klasikal yang terus meningkat dari pra penelitian, siklus I, dan siklus II. Perbandingan kenaikan tersebut hasilnya dapat disajikan dalam gambar 2.

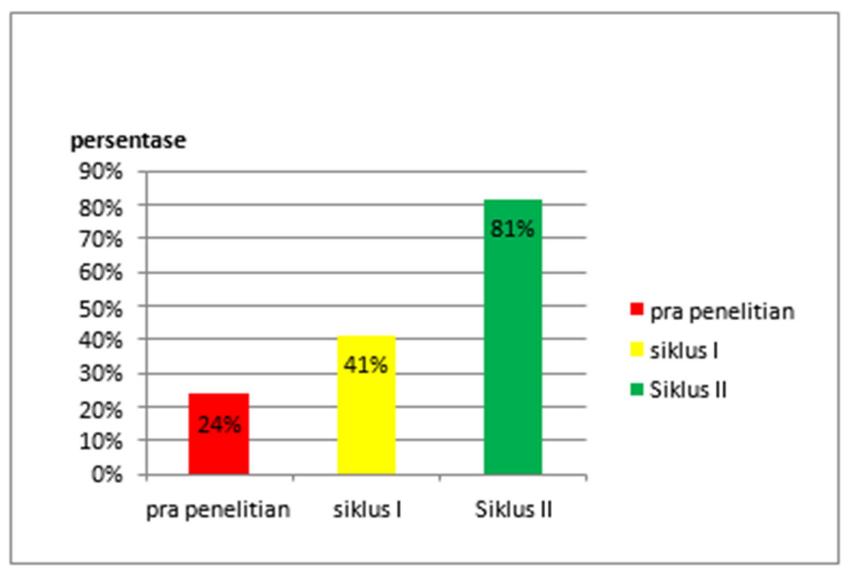

Gambar 2 Persentase Perbandingan Ketuntasan Belajar Ranah Kognitif Pra Penelitian, Siklus I, dan Siklus II 
Berdasarkan hasil pada gambar 2, maka dapat disimpulkan ketuntasan belajar yang memenuhi KKM maupun belum memenuhi KKM sseperti data yang disajikan pada table 5 .

Tabel 5. Perbandingan KKM pra penelitian, siklus I, dan siklus II

\begin{tabular}{cccccccc}
\hline \multirow{2}{*}{ No } & \multirow{2}{*}{ Krietria } & \multicolumn{2}{c}{ Pra Penelitian } & \multicolumn{2}{c}{ Siklus I } & \multicolumn{2}{c}{ Siklus II } \\
& & Frekuensi & Persentase & Frekuensi & Persentase & Frekuensi & Persentase \\
\hline 1 & $\geq$ KKM & 9 & $24 \%$ & 15 & $41 \%$ & 31 & $84 \%$ \\
2 & $\leq$ KKM & 28 & $76 \%$ & 22 & $59 \%$ & 6 & $16 \%$ \\
\hline & Jumlah & 37 & $100 \%$ & 37 & $100 \%$ & 37 & $100 \%$ \\
\hline
\end{tabular}

Berdasarkan penelitian yang dilakukan pada saat proses pembelajaran diperoleh data nilai praktik siswa. Nilai praktik siklus I dan siklus II dapat dilihat dalam tabel 6.

Tabel 6. Hasil Nilai Praktik Siklus I dan Siklus II

\begin{tabular}{clcc}
\hline No & \multicolumn{1}{c}{ Hasil Tes } & Siklus I & Siklus II \\
\hline 1. & Nilai Tertinggi & 85 & 90 \\
2. & Nilai Terendah & 60 & 65 \\
3. & Nilai rata-rata & 72,13 & 78,66 \\
4. & Jumlah siswa tuntas & 26 & 35 \\
5. & Jumlah siswa tidak tuntas & 11 & 2 \\
6. & Persentase ketuntasan KBM & $70 \%$ & $95 \%$ \\
\hline
\end{tabular}

Berdasarkan tabel 6 diketahui ada peningkatan hasil tes nilai keterampilan siswa. Peningkatan nilai praktik dapat dilihat dari nilai rata-rata siswa dan persentase ketuntasan klasikal yang meningkat. Hasil kenaikan tersebut disajikan pada gambar 3.

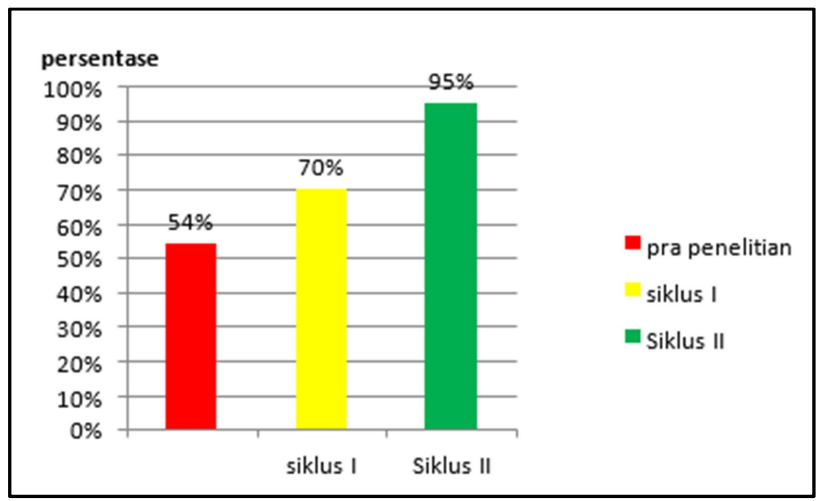

Gambar 3. Persentase Perbandingan Ketuntasan Klasikal Nilai Praktik

Pra Penelitian, Siklus I, dan Siklus II

Berdasarkan hasil pada gambar 3, maka dapat disimpulkan ketuntasan belajar baik diatas KKM maupun dibawah KKM seperti data pada table 7. Berdasarkan hasil pengamatan tingkat motivasi belajar siswa pada siklus II, diketahui bahwa rata-rata tingkat motivasi belajar siswa semakin naik dari rata-rata sebelumnya yang hanya $58 \%$ dan tergolong kriteria baik meningkat sebesar 19\% menjadi $77 \%$. 
Tabel 7. Perbandingan KKM Nilai Praktik Pra Penelitian, Siklus I, dan Siklus II

\begin{tabular}{lccccccc}
\hline No & Krietria & \multicolumn{2}{c}{ Pra Penelitian } & \multicolumn{2}{c}{ Siklus I } & \multicolumn{2}{c}{ Siklus II } \\
& & Frekuensi & Persentase & Frekuensi & Persentase & Frekuensi & Persentase \\
\hline 1 & $\geq$ KKM & 20 & $54 \%$ & 26 & $70 \%$ & 35 & $95 \%$ \\
2 & $\leq$ KKM & 17 & $46 \%$ & 11 & $30 \%$ & 2 & $5 \%$ \\
\hline & Jumlah & 37 & $100 \%$ & 37 & $100 \%$ & 37 & $100 \%$ \\
\hline
\end{tabular}

Pada gambar 3 dapat terlihat dengan jelas adanya peningkatan skor rata-rata dari masing-masing aspek dari siklus I menuju siklus II. Peningkatan rata-rata keseluruhan mengalami kenaikan sebesar 19\% dari siklus I sebesar 58\% naik menjadi $77 \%$ pada siklus II. Seperti pada tekun menghadapi tugas naik sebesar $27 \%$ dari siklus I menjadi $80 \%$ yang berarti siswa tekun mengerjakan tugas atau proyek yang diberikan guru dan juga aktif hadir dalam kelas semakin baik, kemudian aspek ulet menghadapi kesulitan naik sebesar $20 \%$ dari sebelumnya siklus I 55\% naik menjadi $75 \%$ pada siklus II menunjukan siswa yang mempunyai sikap sabar terhadap tugas yang sulit dan berusaha mengadapi kesulitan semakin baik, selanjutnya aspek minat terhadap masalah naik sebesar $14 \%$ dari siklus I $64 \%$ naik menjadi $78 \%$ pada siklus II menunjukan siswa terbiasa dalam mengikuti pelajaran dan semangat dalam mengikuti proses pembelajaran semakin baik. Peningkatan juga terjadi pada aspek senang bekerja mandiri dalam kelompok yang naik sebesar $22 \%$ dari siklus I $54 \%$ naik menjadi $76 \%$ pada siklus II yang menunjukan siswa lebih mandiri dalam penyelesaian tugas-tugas/PR dengan kelompoknya dan menggunakan kesempatan belajra diluar jam pelejaran bersama kelompoknya sangat baik, kemudian yang terakhir yaitu aspek senang mencari dan memecahkan masalah naik sebesar $27 \%$ dari sebelumnya siklus I 50\% naik menjadi $77 \%$ pada siklus II yang artinya siswa siswa antusias menemukan pemecahan masalah dalam kelompoknya dan tanggap dalam menyelesaikan permasalahn dalam kelompoknya., sehingga dapat dikatakan bahwa tingkat motivasi belajar siswa pada siklus II mengalami kenaikan dari siklus I.

Sebelum memulai penelitian, peneliti terlebih dahulu melakukan observasi untuk mengetahui kondisi awal sebelum pemberian tindakan dilakukan. Observasi dilakukan pada kelas yang akan diteliti yaitu kelas X TKJ SMK Negeri 1 Painan . Berdasarkan hasil observasi pra penelitian menunjukan hasil belajar masih rendah. Hali ini ditunjukan dari sejumlah 37 siswa, hanya 9 siswa yang nilainya mencapai ketuntasan belajar dan 28 siswa tidak tuntas belajar. Rata-rata nilai siswa sebelum tindakan adalah 53,10 dengan persentase ketuntasan klasikal sebesar 24\%. Padahal ketuntasan belajar dikatakan berhasil apabila terjadi perubahan perilaku yang positif pada diri peserta didik atau setidaknya kurang lebih $75 \%$. Analisis hasil tes evaluasi hasil belajar siswa pada siklus I menggunakan model pembelajaran Reciprocal teaching dalam mata pelajaran pemrograman dasar mengalami peningkatan dibandingkan pada saat kondisi pra penelitian. Hal ini ditunjukan dari hasil nilai rata-rata siswa sebesar 65,6 dibandingkan keadaan pra penelitian dengan rata-rata 53,10. Nilai tertinggi sebesar 84 dengan frekuensi perolehan sebanyak 2 siswa dan persentase sebesar 5\%, sebaliknya nilai terendah sebesar 32 menunjukan perolehan yang sama dengan nilai tertinggi. Dengan ketuntasan klasikal yang dicapai siklus I naik $17 \%$ dari sebelumnya $24 \%$ saat pra 
penelitian menjadi 41\% pada siklus I dari jumlah siswa 37 siswa. Pada saat siklus I peningkatan hasil belajar masih belum mengalami peningkatan yang signifikan. Selain dari pencapaian ketuntasan klasikal belum mencapai indikator keberhasilan kurang lebih sebesar $75 \%$.

Analisis hasil tes evaluasi siklus II, menunjukan bahwa nilai rata-rata yang dicapai siswa kelas X TKJ naik sebesar 11,00 dari siklus I 65,6 naik menjadi 76,6 pada siklus II. Nilai tertinggi sebesar 92 dengan frekuensi perolehan sebanyak 3 siswa dan persentase sebesar $8 \%$, sedangkan nilai terendah sebesar 48 dengan frekuensi perolehan sebanyak 1 siswa dan persentase sebesar 3\%.Dengan ketuntasan klasikal pada siklus II naik $40 \%$ dari sebelumnya $41 \%$ saat siklus I naik menjadi $81 \%$ saat siklus II dari total siswa sejumlah 37 siswa. Penilaian hasil belajar tidak hanya pada tes evaluasi tetapi juga pada tes keterampilan atau praktik. Hasil tes praktik diperoleh peneliti saat observasi. Berdasarkan hasil nilai praktik, rata-rata nilai praktik pada saat kondisi pra penelitian 66,57 .

Analisis hasil evaluasi tes praktik menggunakan model pembelajaran Reciprocal teaching saat pelaksanaan siklus I menunjukan rata-rata meningkat menjadi 72,13 dibandingkan keadaan pra penelitian dengan rata-rata 66,57. Nilai tertinggi sebesar 85 dengan frekuensi perolehan sebanyak 3 siswa dan persentase sebesar $8 \%$, sedangkan nilai terendah sebesar 60 dengan frekuensi perolehan sebanyak 8 siswa dan persentase sebesar 22\%. Dengan ketuntasan klasikal yang dicapai siklus I naik 24\% dari sebelumnya 54\% saat pra siklus menjadi 70\% pada siklus I dari jumlah siswa 37 siswa. Akan tetapi, ketuntasan klasikal belum mencapai indikator kurang lebih 75\%. Jumlah siswa yang $\geq$ KKM sebanyak 26 siswa atau sekitar 70\% dan yang $\leq$ KKM sebanyak 11 siswa atau sekitar $30 \%$.

Nilai rata-rata praktik yang dicapai siswa kelas X TKJ pada siklus II naik sebesar 6,53 dari siklus I sebesar 72,13 naik menjadi 78,66 pada siklus II. Nilai tertinggi sebesar 90 dengan frekuensi perolehan sebanyak 5 siswa dan persentase sebesar $14 \%$, sedangkan nilai terendah sebesar 65 dengan frekuensi perolehan sebanyak 2 siswa dan persentase sebesar 5\%. Penelitian tindakan kelas ini dapat diakhiri karena kedua nilai sudah mencapai indikator keberhasilan yang telah ditentukan yaitu $75 \%$. Selama pelaksanaan pembelajaran dengan model pembelajaran Repirocal Teaching ada beberapa kendala yang dihadapi dalam penelitian. Sebagai upaya mengatasi kendala tersebut dilakukan refleksi. Refleksi merupakan kegiatan untuk mengemukakan kembali apa yang sudah terjadi. Pada saat pelaksanaan tindakan siklus I kendala yang terjadi pada saat proses diskusi siswa masih ramai dan proses diskusi kurang terarah sehingga proses berbagi pengetahuan menjadi kurang optimal. Padahal prinsip pembelajaran lebih menekankan siswa yang berpengetahuan lebih untuk mengajari siswa yang berpengetahuan rendah. Hal tersebut dikarenakan siswa kurang sabar dalam menghadapi siswa yang berpengetahuan rendah.

Berdasarkan kekurangan pada siklus I tersebut, maka perlu dilakukan refleksi pada pelaksanaan siklus II. Hal yang dilakukan pada siklus II adalah proses diskusi lebih teratur dengan menggunakan prinsip memberikan pertanyaan pada setiap kelompok dengan pertanyaan yang berbeda pada setiap individu kemudian individu tersebut wajib menjawab pertanyaan dengan benar dan pada saat proses pengerjaan tes evaluasi siswa lebih bersungguh-sungguh dengan menerapkan pengawasan ynag lebih ketat agar siswa tidak mencontek. Model pembelajaran Reciprocal teaching memiliki kelebihan maupun kekurangan. Kelebihan model pembelajaran Reciprocal teaching adalah siswa yang berkemampuan lebih bisa membantu siswa yang berkemampuan rendah dalam proses pembelajaran dengan sistem pembagian kelompok yang heterogen 
berdasarkan kemampuan siswa. Kekurangan dari model pembelajaran Reciprocal teaching adalah kurangnya waktu siswa dalam berdiskusi maupun mempresentasikan sehingga kurang maksimal dalam menilai kemampuan siswa memahami materi.

\section{KESIMPULAN DAN SARAN}

Berdasarkan hasil penelitian dan pembahasan yang telah dilakukan dapat disimpulkan bahwa penerapan model pembelajaran reciprocal teaching pada mata pelajaran pemrograman dasar dapat meningkatkan motivasi belajar siswa kelas X TKJ SMK Negeri 1 Painan. Kemudian model pembelajaran reciprocal teaching yang digunakan juga dapat meningkatkan hasil belajar siswa kelas X TKJ SMK Negeri 1 Painan.

\section{REFERENSI}

[1] R. S. Harahap, “ Implementasi pendekatan reciprocal teaching dengan strategi pembelajaran card sort untuk meningkatkan aktivitas dan hasil belajar akuntansi siswa kelas xii bm smk muhammadiyah-8 medan tahun pembelajaran 2013/201," Medan, 2013.

[2] A. G. Valentino, "Penerapan pendekatan strategi pengajaran timbal balik (reciprocal teaching) untuk meningkatkan kemampuan berkomunikasi, prestasi dan motivasi belajar pada mata pelajaran pengetahuan dasar teknik mesin siswa kelas X di SMKN 6 Malang oleh Ade Gita Valentino,” Malang, 2010. [Online]. Available: ttp://library.um.ac.id/ptk/index.php/index.php?mod=detail\&id=42752.

[3] D. G. Allen, L. M. Shore, and R. W. Griffeth, "The Role of Perceived Organizational Support and Supportive Human Resource Practices in the Turnover Process," J. Manage., vol. 29, no. 1, pp. 99-118, 2003, doi: 10.1177/014920630302900107.

[4] AM Sardiman, Interaksi \& motivasi belajar mengajar. Jakarta: PT RajaGrafindo Persada, 2007.

[5] H. B. Uno, Teori Motivasi \& Pengukurannya: Kajian \& Analisis Di Bidang Pendidikan. Jakarta: Bumi Aksara, 2008.

[6] S. B. Djamarah, Psikologi Belajar. Jakarta: PT. Rineke Cipta, 2002.

[7] O. Hamalik, Perencanaan Pengajaran Berdasarkan Pendekatan Sistem. Jakarta: Bumi Aksara, 2008.

[8] O.- Hamalik, Perencanaan Pengajaran Berdasarkan Pendekatan Sistem. Jakarta: Bumi Aksara, 2010.

[9] C. T. A. Achmad Rifa'i, Psikologi Pendidikan. Semarang: Pusat Pengembangan MKU/MKDK-LP3: Universitas Negeri Semarang, 2012.

[10] Kemendikbud, Salinan Permendikbud Nomor 23 tahun 2016 Tentang Standar 
Penilaian Pendidikan, no. Standar Penilaian Pendidikan. 2016, pp. 1-12.

[11] W. Sanjaya, Strategi Pembelajaran Berbasis Standar Proses Pendidikan. Jakarta: Kencana Prenada Media, 2006.

[12] K. Nisa Nurul Fitri and L. Sugiyanti, "Pembelajaran Program Aplikasi Microsoft Word Melalui Penerapan Model Student Facilitator and Explaining," Din. Pendidik., vol. 4, no. 1, pp. 52-59, 2014.

[13] N. Efendi, "Pendekatan Pengajaran Reciprocal Teaching Berpotensi Meningkatkan Ketuntasan Hasil Belajar Biologi Siswa SMA,” Pedagog. J. Pendidik., vol. 2, no. 1, p. 84, 2013, doi: 10.21070/pedagogia.v2i1.49. 
Halaman ini sengaja dikosongkan 